\title{
NEGAÇÃO DA LAICIDADE, PENSAMENTO AUTORITÁRIO E DESCẢRACTERIZAÇÃO DA ESCOLA PÚBLICA NO BRASIL
}

\author{
NEGACIÓN DEL SECULARISMO, PENSAMIENTO AUTORITARIO Y \\ DESCARACTERIZACIÓN DE LA ESCUELA PÚBLICA EN BRASIL
}

\author{
DENIAL OF SECULARISM, AUTHORITARIAN THINKING AND \\ DECHARACTERIZATION OF PUBLIC SCHOOL IN BRAZIL
}

\author{
André Luiz PACHECO ${ }^{1}$ \\ José Luis DERISSO ${ }^{2}$
}

\begin{abstract}
RESUMO: A descaracterização da escola pública relativamente ao seu fim de socializar conhecimentos acumulados e elaborados historicamente no âmbito da ciência, da filosofia e da arte ocorre por meios e artifícios diversos. Neste artigo identificamos quatro deles, a saber: o Ensino Religioso, instituído em 1931, uma clara negação do caráter laico da escola e do Estado; o combate à abordagem da questão de gênero sob o argumento de defesa da família; o Programa Escola Sem Partido que por meio de projetos de lei desde o Senado Federal até as câmaras municipais objetiva implantar a censura às reflexões e abordagens críticas da sociedade no interior das escolas; e a Reforma do Ensino Médio que aprofunda a orientação tecnicista e pragmática da educação escolar ao passo que reduz a carga horária de algumas disciplinas e exclui outras. Tal cenário privilegia o desenvolvimento de uma educação de adaptação acrítica das crianças e dos jovens à ordem econômica e social do capitalismo e à moral que melhor lhe representa, cerceando o florescimento de pedagogias críticas contra hegemônicas.
\end{abstract}

PALAVRAS-CHAVE: Laicidade. Pensamento autoritário. Escola pública. Brasil.

RESUMEN: La descaracterización de la escuela pública en relación con su propósito de socializar los conocimientos acumulados y elaborado históricamente en el contexto de la ciencia, la filosofía y el arte ocurre por diversos medios y artificios. En este artículo identificamos cuatro de ellos, a saber: la educación religiosa, establecida en 1931, una clara negación del carácter secular de la escuela y del estado; Combatir el enfoque de las cuestiones de género en el argumento de la defensa de la familia; El programa escolar sin una parte que a través de proyectos de ley del Senado Federal a las cámaras municipales tiene como objetivo implantar la censura en las reflexiones y enfoques críticos de la sociedad dentro de las escuelas; Y la reforma de la escuela secundaria que profundiza la orientación técnica y pragmática de la educación escolar,

\footnotetext{
1 Universidade Estadual do Oeste do Paraná - (UNIOESTE), Campus de Cascavel - PR - Brasil. Graduado em História, Mestrando no Programa de Pós-graduação em Educação e Professor na rede municipal de ensino de Cascavel - PR. ORCID: <https://orcid.org/0000-0003-3502-3790>.

2 Universidade Estadual do Oeste do Paraná - (UNIOESTE), Campus de Cascavel - PR - Brasil. Professor Adjunto do Colegiado de Pedagogia e do Programa de Pós-graduação em Educação. ORCID: <http://orcid.org/0000-0003-4044-4493>. E-mail: joseluisderisso@yahoo.com.br
}

RPGE- Revista on line de Política e Gestão Educacional, Araraquara, v. 22, n. 2, p. 646-667, maio/ago., 2018. E-ISSN:1519-9029. DOI: $10.22633 /$ rpge.v22.n2.maio/ago.2018.11667 
al tiempo que se reduce la carga de trabajo de algunas disciplinas y se excluye a los demás. Este escenario favorece el desarrollo de una educación de adaptación no crítica de niños y jóvenes al orden económico y social del capitalismo y a la moral que mejor lo representa, coarte el florecimiento de la pedagogías crítica contra la hegemonía.

PALABRAS CLAVE: Secularidad. Pensamiento autoritario. Escuela pública. Brasil.

ABSTRACT: The distortion of the public school in relation to your order to socialize historically accumuled and developed knowledge in the contexto of science, philosophy and art occurs by various means and devices. In this article we identified four of them, namely: the Religious Education, that was established in 1931, a clear denial of the secular character of the school and the State; the combating gender approach on the grounds of protection of the family; the Program Escola Sem Partido by means of projects from the Senate even the municipalities aims to deploy the censorship to reflections and critical approaches about society into the schools; and the High School Reform which deepens the technical and pragmatic orientation of school education while reducing the workload of some subjects and excludes others. Such a scenario favors the development of uncritical adaptation form of education for children and young people to social and economic order of capitalism and of moral which best represents itself, abridging the flourishing of critic pedagogies not hegemonics.

KEYWORDS: Laity. Authoritarian thought. Public School. Brazil.

\section{Introdução}

Após mais de 130 anos de proclamada a república no Brasil e de ocorrer a separação entre Igreja e Poder Civil, a laicidade do Estado continua sendo questionada por religiosos. Sob pressão principalmente da Igreja Católica, concessões foram feitas desde o início do período republicano e novos projetos pretendem impor novos retrocessos acerca da laicidade no plano constitucional.

Os três temas indicados no título do presente artigo são abordados e expostos na ordem que ali se apresenta, antecedidos de um primeiro tópico sobre os antecedentes históricos da constituição da República no que tange ao regime de união entre Igreja e Estado no Brasil. No segundo tópico, abordamos a evolução do tratamento jurídico da disciplina escolar Ensino Religioso desde sua implantação em 1931 até a Lei 9475/97 que reformulou a Lei Federal no 9394/96 no tocante à essa matéria. No terceiro, abordamos a questão de gênero e os modos pelos quais setores religiosos fazem oposição a que temáticas relacionadas e a esta questão sejam tratadas nas escolas. A seguir, no quarto tópico, nos ocupamos dos projetos de lei Escola-sem-Partido e da reforma do ensino Médio, no que tange principalmente aos aspectos autoritários, 
contrários à laicidade ou que desvirtuam o desenvolvimento do ato educativo na perspectiva da formação humana integral. Por fim apresentamos nossas considerações finais.

\section{Antecedentes históricos: o regime de união entre Igreja e Estado}

Antes mesmo de iniciar a colonização do Brasil, o Estado português controlava a estrutura eclesiástica da Igreja Católica por meio do regime do padroado régio. A relação de dependência mútua entre Estado e Igreja remete à própria fundação do Reino, em 1128, quando D. Afonso Henrique, após vencer os mouros no processo de reconquista, proclamou vassalagem ao Papa e se comprometeu a pagar o censo à Santa Sé que em 1144 emite a carta que sacramenta a aliança, conforme Azzi (1987):

[...] o Papa Celestino II escrevia ao príncipe português louvando-o pela resolução de fazer homenagem à Sé Apostólica 'da terra cujo regimento Deus lhe confiara'. É com este ato político-religioso que se inicia a monarquia portuguesa. (AZZI, 1987, p. 19-20)

Após a nomeação pelo Papa Adriano, em 1522, do rei D. João III a Grão-mestre da Ordem de Cristo (poder de caráter hereditário),

Os reis de Portugal tornavam-se, portanto, os chefes efetivos da Igreja por duas razões convergentes: pelos direitos de padroado e pelo título de Grão-mestre da Ordem de Cristo. Este último título conferia aos reis de Portugal também o regime espiritual, devendo, portanto, zelar pela vida cristã nas colônias portuguesas. (AZZI, 1987, p. 21-22)

Sendo assim, a colonização do Brasil, além de sua lógica comercial expansionista, se traveste de um caráter de cruzada em nome da fé cristã para expansão da cristandade, e foi justamente a partir dessa ótica que os jesuítas integraram o projeto colonizador português, como missionários com caráter oficial e financiados pelo Estado português (DERISSO; SOUZA, 2017).

De 1549 a 1580 somente os jesuítas foram autorizados a manter com regularidade atividades missionárias no Brasil, o que lhes garantiu um monopólio missionário que somente foi quebrado com a unificação das coroas portuguesa e espanhola (1580/1640) que permitiu a presença de outras ordens religiosas.

A atividade dos jesuítas se desenvolvia em dois campos: no trabalho missionário junto aos indígenas e na educação dos filhos dos proprietários coloniais. Atividade esta que foi fundamental não apenas para impor a apropriação da língua lusófona, mas 
também para estabelecer a fé católica e consequentemente conter comportamentos moralmente devassos, sexualmente impróprios, bem como as eventuais desobediências hierárquicas dos padres e dos colonizadores.

O objetivo da doutrina de Inácio de Loyola era a santificação pessoal e a atividade apostólica. Para tanto, os jesuítas tomavam por base os Exercícios Espirituais e os adaptavam, no cotidiano de seus afazeres práticos, como "método para a boa administração da Companhia de Jesus." Nos Exercícios Espirituais Loyola destaca o papel importante da confissão e da penitência. Sugere que o fiel faça um exercício de reflexão sobre os pecados cometidos antes de se confessar. $\mathrm{Na}$ verdade, esse é o embrião da casuística inaciana, que era um método de análise e meditação profunda de exame de consciência. (PINHEIRO, 2007)

Em 1759, um alvará régio expulsou os jesuítas do Brasil e proibiu sua atuação educativa, pondo fim a um ciclo de quase duzentos anos durante o qual os jesuítas promoveram uma educação religiosa. Nos anos que se seguem, a religião continua a se fazer presente na escola por meio da catequese e da História Sagrada, uma decorrência do regime de união entre a Igreja e o Estado que impunha o catolicismo com exigência para o exercício de qualquer função pública, o que continua a existir após a independência (1822).

Durante o período imperial (1822/89) os regimentos das poucas faculdades brasileiras exigiam um juramento católico tanto do professor como do estudante. A Constituição de 1824 estabelecia no seu artigo $5^{\circ}$ que

A Religião Católica Apostólica Romana continuará a ser a religião do Império. Todas as outras religiões serão permitidas com seu culto doméstico, ou particular, em casas para isso destinadas, sem forma alguma exterior de templo. (BRASIL, 1824)

Esta mesma constituição proclamava no seu artigo 179 a liberdade de consciência, o que consistia numa contradição, conforme observou Barros (1997):

Ora, a liberdade de consciência, embora proclamada em tese no art. 179 da Constituição do Império, era não só limitada pelo Código Criminal e pelos Estatutos das faculdades, mas também pela própria Carta que a assegurava, através do art. $5^{\circ}$ e do parágrafo $3^{\circ}$ do art. 95 , este último a excluir do direito fundamental de tornar-se representante do povo 'os que não professarem a religião do Estado'. (BARROS, 1997, p. 329) 
O regime do padroado, transposto de Portugal para o Estado Imperial brasileiro, foi expresso no artigo 102 da Constituição de 1824 que estabelecia ser de competência do Imperador nomear bispos e prover os benefícios eclesiásticos.

Com a promulgação da primeira Constituição da República em 1891, dois anos após o golpe militar que instaurara o novo regime, o Estado brasileiro passa a ser laico e com isso a Igreja Católica perde o importante status de religião oficial. Entretanto, isso agora permite aos católicos terem autonomia em relação à própria legislação da fé, obedecendo diretamente às ordens do Vaticano que não necessitam mais do aval do Estado.

No entanto, apesar das críticas católicas ao laicismo republicano, dois fatos não podem ser negados: primeiro, apesar do peso simbólico da separação Estado/Igreja, como marco da derrota da Igreja Católica, é importante notar que esta se viu livre do controle do Estado e pode se dedicar ao enquadramento do clero e de seus ministros, o que antes era impossível pela exigência do "placet" imperial para validar as leis apostólicas que provinham de Roma; segundo, as leis de secularização que foram objeto de negociação por mais de um ano entre o episcopado representado por D. Macedo Costa- o mesmo da "questão religiosa" e agora arcebispo da Bahia e primaz do Brasil- e o governo republicano representado pelo Ministro da Fazenda Rui Barbosa, poderiam ter sido muito piores para a Igreja. (DERISSO, 2006, p. 33).

Rui Barbosa, Ministro da Fazenda do período republicano, biograficamente é tido como um fervoroso católico que apesar de republicanamente defender a separação total entre Igreja e Estado, foi autor de um prosélito discurso no Colégio Anchieta em 1903 em que entre outras coisas, buscava na história os grandes líderes mundiais que haviam recorrido ao Onipotente para resolver as mazelas de seus países.

Percorrei toda a série dos grandes estadistas americanos, daqueles, em particular, que sopesaram as maiores responsabilidades do governo: nenhum esqueceu a Deus em horas solenes. Jefferson mesmo, cujo espírito político se educara sob o influxo das teorias francesas, e convivera intimamente, em França, com os chefes da incredulidade, o próprio Jefferson repassava de acentos cristãos as suas mais solenes comunicações ao Congresso. Sua mensagem inaugural, em cujo curso aludia à "religião benfazeja" e à "Providência, que nos governa", terminava com esta súplica: Queira esse Poder infinito, que rege os destinos do universo, guiar-nos as deliberações para o melhor, azandolhes sucesso favorável ao nosso descanso e prosperidade. Washington, antes dele, dera o exemplo memorável. Pronunciando, em abril de 1789, a sua primeira fala ao Congresso, nas palavras lhe reverberava a unção de um levita oficiando no Tabernáculo. (BARBOSA, 1903). 
Perceptível que mesmo com o esforço de um republicano convicto, a ideologia religiosa e a moral conservadora sempre fizeram parte dos discursos estadistas que, arraigados na fé católica, permitiam-se estabelecer a moral judaico-cristã nos momentos de discursos políticos, uma vez que a própria população estava acostumada a entrelaçar a vida cotidiana com a própria fé.

A Constituição de 1934, promulgada na pós-revolução de 1930, foi responsável por novamente entrelaçar Estado e Igreja, haja vista que o que antes era concebido como separação total, agora passa a ser visto, de acordo com Leite (2007) como um regime de Cooperação, uma resposta reacionária à laicidade da Carta Magna de 1891.

No decorrer da campanha para a eleição dos deputados constituintes, os católicos criaram a Liga Eleitoral Católica (LEC) que se pautava em dez pontos entre os quais se destacavam a promulgação da Constituição em nome de Deus, a proibição do divórcio, o combate a toda legislação contrária aos princípios fundamentais da doutrina católica e o ensino religioso nas escolas públicas. (MOURA; ALMEIDA, 1997).

No ano que se seguiu à Revolução de Trinta, a Igreja Católica logrou obter conquistas importantes para suas pretensões de fazer frente à laicidade da República: a inauguração da estátua do Cristo Redentor num ato oficial que reuniu todo o ministério de Getúlio Vargas ao lado dos bispos brasileiro, momento em que foram entregues a Vargas a pauta de reivindicações católica; o estabelecimento do feriado de 12 de outubro, dia de Nossa Senhora Aparecida, padroeira do Brasil; e a instituição do ensino religioso facultativo nas escolas públicas por meio de um decreto.

Cabe dizer que os dez pontos da LEC foram aprovados pela Constituinte e incorporados à Constituição de 1934.

\section{Ensino Religioso nas escolas públicas}

A pressão da Igreja Católica logrou em 1934 a inclusão de suas reivindicações na Carta Constitucional, entre elas o ensino religioso facultativo, porém contemplado em classes e horários normais de funcionamento das escolas públicas.

A constituição de 1946 reafirma o Ensino Religioso e indica a elaboração em âmbito nacional de uma lei de diretrizes e bases da educação (LDB). Tal lei, que em 1946 foi afirmada como urgente, passou por quinze anos de letargia, sendo promulgada somente em 1961, após intensos embates protagonizados de um lado pelos católicos e de outro por defensores dos princípios da escola republicana, sobretudo de seu caráter 
público e laico. Naquele contexto, os católicos levantavam a bandeira da liberdade de ensino para sustentarem que o Estado deveria financiar, por meio de bolsas de estudo, o ensino promovido pelas escolas católicas, assim como - para lograr o apoio das outras escolas privadas - de todos aqueles que optassem por estudar fora da rede pública. E desse modo conquista subsídios para as escolas privadas além do reconhecimento de que as mesmas não visam lucros, pois seriam filantrópicas.

Em relação ao Ensino Religioso, não houve grande alteração até mesmo pelo fato de que a existência desta disciplina já estava contemplada na Constituição. De acordo com a primeira LDB, lei 4024/61:

[...] Art. 97. O Ensino Religioso constitui disciplina dos horários normais das escolas oficiais e é de matrícula facultativa e será ministrado sem ônus para os cofres públicos, de acordo com a confissão religiosa do aluno, manifestada por ele, se for capaz, ou por seu representante legal ou responsável.

$\S 1$. A formação de classe para o Ensino Religioso independe do número de alunos

$\S$ 2. O registro dos professores de Ensino Religioso será realizado perante a autoridade religiosa respectiva (...)

Após o golpe militar e o Ato Institucional número 5, o novo regime redige e promulga uma nova legislação educacional, dez anos depois da primeira, por meio da Lei 5692/71 que mantém a formulação sobre o Ensino Religioso, mas, no entanto, amplia a oferta desta disciplina para o Ensino Médio, na época chamado de segundo grau.

Além do Ensino Religioso, o regime militar cria a disciplina Educação, Moral e Cívica cujo objetivo era inflamar o nacionalismo com a ideia de nação totalitária (única, sem divisões) e de unidade nacional (todos trabalhando pela nação). Aqui, a veia conservadora ganha além do viés moral e religioso, o viés político de propaganda anticomunista, uma vez que em plena guerra fria, a possibilidade de uma revolução poderia levar a população a viver uma catarse social que poderia trazer o "insólito regime" para terras brasileiras.

A moral vislumbrada pelos militares era, segundo o Parecer 94/71 do Conselho Federal de Educação, a moral religiosa:

[...] se as raízes da Moral e da Religião de tal forma se entrelaçam, dentro da alma humana, como proceder-se a uma dissociação radical entre as duas?

Surge aqui, como terceira decorrência da aconfessionalidade da Constituição do Brasil, a decorrência de que o fundamento religioso

RPGE- Revista on line de Política e Gestão Educacional, Araraquara, v. 22, n. 2, p. 646-667, maio/ago., 2018. E-ISSN:1519-9029. 
que, segundo o que se depreende do Decreto-Lei $\mathrm{n}^{\circ}$. 869/69, deve estar subjacente à Moral a ser ensinada na Educação Moral e Cívica, será tomada da chamada Religião Natural. (BRASIL, 1971).

Com a redemocratização, a Constituição de 1988 reafirma o caráter laico do Estado brasileiro, reforçando-o com a garantia da liberdade de expressão individual "de crença religiosa, de convicção filosófica ou política" (BRASIL, 1988, 5, VIII). A grande contradição se configura na manutenção do Ensino Religioso nas escolas públicas de nível fundamental em uma carta magna que proíbe lugares públicos de estabelecerem cultos religiosos, conforme se pode aprender desta passagem:

Art. 19. É vedado à União, aos Estados, ao Distrito Federal e aos Municípios:

I - estabelecer cultos religiosos ou igrejas, subvencioná-los, embaraçar-lhes o funcionamento ou manter com eles ou seus representantes relações de dependência ou aliança, ressalvada, na forma da lei, a colaboração de interesse público; (BRASIL, 1988 Grifo nosso ${ }^{3}$ ).

Posterior à Constituição, nova lei de diretrizes da educação foi elaborada e materializada na lei $\mathrm{n}^{\circ} 9394$ de 20 de dezembro de 1996 que após receber emenda pela Lei 9475/97 estabelece no seu artigo 33 que

O ensino religioso, de matrícula facultativa, é parte integrante da formação básica do cidadão e constitui disciplina dos horários normais das escolas públicas de ensino fundamental, assegurado o respeito à diversidade cultural religiosa do Brasil, vedadas quaisquer formas de proselitismo. (Redação dada pela Lei $\mathrm{n}^{\circ}$ 9.475, de 22/07/1997)

Notem a formulação "sem ônus para os cofres públicos" foi suprimida.

A implantação dessa disciplina nas escolas públicas foi palco de grandes embates entre os defensores da laicidade e as entidades religiosas majoritárias no Brasil. Ainda hoje se questiona a viabilidade de uma disciplina tendenciosamente religiosa em um sistema de educação que preza pela liberdade e pela criticidade, relativamente às teorias sociais e às concepções filosóficas ou religiosas. Mesmo que vedado o proselitismo, o Ensino Religioso na escola pública tende a trazer para o campo educacional questões ou até mesmo embates do campo religioso, e nesse sentido pode se tornar fator decisivo para a inclinação do ensino sob viés da religião com maior número de adeptos.

\footnotetext{
${ }^{3}$ Esta ressalva não existia no texto original da Constituição de 1891, sendo acrescido no texto da Constituição de 1967.
} 


\section{A questão de gênero}

A evolução da ciência moderna leva ao surgimento de novos questionamentos e originam novos debates sociais. Apesar de não ser necessariamente inédita, a discussão acerca da identidade de gênero e orientação sexual ganhou força nos últimos anos, e no campo progressista, discutem-se formas de expandir o debate público, entendo que um dos caminhos mais viáveis seria por meio da escola.

É nítida a presença de comportamentos sexuais distintos em relação ao padrão, atualmente, vigente desde as antigas civilizações, tidos inclusive como naturais e até mesmo necessários para o próprio desenvolvimento do ser.

Nos povos antigos a homossexualidade era encarada com normalidade, talvez até mais do que isso, pois representava uma evolução da sexualidade. A homossexualidade estava presente tanto na Grécia, quanto no Império Romano e recebia o nome de pederastia. Termo esse utilizado para designar o relacionamento erótico entre um homem e um menino. Atualmente o termo é utilizado para designar não somente o relacionamento erótico entre um homem e um rapaz, mas também qualquer relação homossexual masculina. A pederastia, na Grécia antiga, era vista sobre vários prismas, dependendo da situação. Entretanto, o que mais se destaca é a pederastia inserida na educação dos jovens rapazes, pois entendiam que a prática da pederastia institucionalizada era necessária para o desenvolvimento da masculinidade dos adolescentes. (DIETER, 2011)

Com o processo de cristianização do Ocidente, a prática homossexual foi sendo tabulada como pecaminosa na medida em que as manifestações relativas às práticas sexuais individuais precisavam ser padronizadas e restritas à finalidade da procriação. Quaisquer manifestações difusas eram taxadas como aberrações a serem combatidas. Nos países mais avançados da Europa, tal como a Inglaterra, o homossexualismo foi criminalizado até o início do século XX, e em vários países africanos e asiáticos ainda continua sendo, com penas que podem chegar até a morte.

É fato que o regime social do patriarcado precede as religiões de matriz judaicocristã. Historicamente, o papel delegado a mulher na sociedade é extremamente restrito e condicionado. Há milênios a sociedade assiste a desigualdade de gênero sendo imposta de maneira violenta a fim de favorecer a propriedade privada do homem, mas nem sempre foi assim.

Historicamente, o poder do homem no seio da família foi precedido por formas de organização social regidas pelo matriarcado, uma vez que a mulher gozava de maior prestígio social e definia a linhagem familiar. No modelo de organização familiar que Engels (1982) e outros antropólogos que o antecederam denominavam "sindiásmica", 
que se constituía numa monogamia mais ou menos fluida, no caso de separação o homem deixava a casa da família (a gens), levando consigo seus pertences que eram basicamente armas e os instrumentos de caça, enquanto a mulher permanecia com os filhos e os utensílios domésticos. A gradual transformação da caça - atividade masculina - em rebanho deu ao homem um poder que antes não possuía, e certamente foi o elemento determinante no aumento do poder paterno até ao desequilíbrio que relegou a mulher e os filhos à condição de propriedade do pai. Basta ler os primeiros livros da Bíblia para se ter uma ideia de como o poder patriarcal era exercido.

Simone de Beauvoir, filósofa francesa do século XX resgata e destaca importantes discussões acerca do papel da mulher, os estereótipos de gênero que favorecem o domínio do patriarcado e a luta feminista pela igualdade. Para ela:

Ninguém nasce mulher: torna-se mulher. Nenhum destino biológico, psíquico, econômico define a forma que a fêmea humana assume no seio da sociedade; é o conjunto da civilização que elabora esse produto intermediário entre o macho e o castrado que qualificam de feminino. Somente a mediação de outrem pode constituir um indivíduo como um outro. Enquanto existe para si, a criança não pode apreender-se como sexualmente diferençada. Entre meninas e meninos, o corpo é, primeiramente, a irradiação de uma subjetividade, o instrumento que efetua a compreensão do mundo: é através dos olhos, das mãos e não das partes sexuais que apreendem o universo. (BEAUVOIR, 1967, p. 9).

Beauvoir, feminista, trata sobre os estereótipos de gênero que levam a exclusão da mulher e ao regime de quase servidão que é, segundo os cristãos, bíblico, já que na carta aos Efésios o apóstolo Paulo afirma que as mulheres devem se manter submissas aos seus maridos. (BÍBLIA, Efésios, 5, 22).

Na contemporaneidade, a filósofa americana Judith Butler promove a discussão acerca das diversas identidades de gênero. Para ela, os estereótipos não podem resumir o ser a meras significações binárias e com isso a determinação do status homem/mulher.

Se o gênero são os significados culturais assumidos pelo corpo sexuado, não se pode dizer que ele decorra de um sexo desta ou daquela maneira. Levada a seu limite lógico, a distinção sexo/gênero sugere uma descontinuidade radical entre corpos sexuados e gêneros culturalmente construídos. Supondo por um momento a estabilidade do sexo binário, não decorre daí que a construção de "homens" aplique-se exclusivamente a corpos masculinos, ou que o termo "mulheres" interprete somente corpos femininos. Além disso, mesmo que os sexos pareçam não problematicamente binários em sua morfologia e constituição (ao que será questionado), não há razão para supor que os gêneros também devam permanecer em número de dois. (BUTLER, 2003, p. 24). 
Contudo, o desenvolvimento de novas teorias acerca da sexualidade e das diversas manifestações da identidade de gênero não foram bem vistas pela religião de modo geral, sobretudo o cristianismo, que critica a discussão em si de tal fenômeno, mas principalmente condena que tais discussões sejam levadas para o interior das escolas.

Um dos primeiros líderes religiosos a criticar os diversos estudos sobre gênero de maneira aberta foi o conservador papa Bento XVI. Para ele, o homem caminha para a autodestruição quando nega os princípios da natureza que lhe são devidos.

O que com frequência é expresso e entendido com a palavra "gender", resolve-se em definitiva na autoemancipação do homem da criação e do Criador. O homem pretende fazer-se sozinho e dispor sempre e exclusivamente sozinho o que lhe diz respeito. Mas desta forma vive contra a verdade, vive contra o Espírito criador. As florestas tropicais merecem, sim, a nossa proteção, mas não a merece menos o homem como criatura, na qual está inscrita uma mensagem que não significa contradição da nossa liberdade, mas a sua condição. Grandes teólogos da Escolástica qualificaram o matrimônio, ou seja, o vínculo para toda a vida entre homem e mulher, como sacramento da criação, que o próprio Criador instituiu e que Cristo sem modificar a mensagem da criação depois acolheu na história da salvação como sacramento da nova aliança. Pertence ao anúncio que a Igreja deve levar o testemunho a favor do Espírito criador presente na natureza no seu conjunto e de modo especial na natureza do homem, criado à imagem de Deus. Partindo desta perspectiva seria necessário voltar a ler a Encíclica Humanae vitae: a intenção do Papa Paulo VI era defender o amor contra a sexualidade como consumo, o futuro contra a pretensão exclusiva do presente e a natureza do homem contra a sua manipulação. (BENTO XVI, 2008).

O fato é que a polêmica ideia de "ideologia de gênero" movimenta hoje o mundo e é capaz de traçar embates vorazes entre progressistas e conservadores mundo afora. $\mathrm{O}$ Brasil, com todo o seu passado cristão, conservador e reacionário, em parte pela herança portuguesa do período da colônia, não foge; de modo que hoje a possibilidade de discussão aberta sobre o tema nas escolas é alvo de grande polêmica.

Toda essa questão gerou uma grande polêmica e trocas de acusações, de um lado progressistas acusando conservadores de homofóbicos, transfóbicos, etc; de outro lado conservadores direcionando acusações de doutrinação ideológica e sexual por parte do campo progressista.

No ano de 2011, o projeto "Escola sem homofobia" de autoria do deputado federal Jean Willys (militante da causa LGBT) causou grande alvoroço dentro e fora das galerias do Congresso Nacional. Segundo o Ministério da Educação, o material 
disponibilizado não possuía conotação erótica e seria destinado apenas a alunos do Ensino Médio. Mesmo assim, o projeto ganhou tamanha repercussão negativa que a então presidente, Dilma Rousseff, vetou integralmente e sem qualquer ressalva o projeto, hoje engavetado.

Em 2014, a aprovação do Plano Nacional de Educação também gerou fortes embates e discussões em âmbito nacional. O apelo à diversidade foi tido por parlamentares cristãos como "um ataque a família, a moral e à integridade psicológica dos alunos", levando o Senado a modificar o texto do plano que fazia alusão às diversidades de gênero e orientação sexual, alterando a diretriz que previa a superação das desigualdades educacionais (inciso III do art. $2^{\circ}$ do substitutivo da Câmara) ao retirar a ênfase na promoção da "igualdade racial, regional, de gênero e de orientação sexual" e substituí-la pela ênfase na "cidadania e na erradicação de todas as formas de discriminação" (BRASIL, 2014, p. 22).

Naquele contexto formou-se um forte $l o b$ religioso sobre os legisladores. O Arcebispo Metropolitano de São Sebastião do Rio de Janeiro, Dom Orani João Tempesta, invocou os fiéis a aderirem à plataforma "Não quero que a Ideologia de Gênero seja inserida no PNE!” contida na página eletrônica da Arquidiocese e endereçada aos deputados federais. Nesta cruzada contra a "ideologia de gênero", os argumentos foram basicamente os mesmos: o conceito de gênero teria sido elaborado pelos marxistas como suporte para a destruição da família, da propriedade privada e das bases da civilização ocidental, estratégia denominada "marxismo cultural", que teria sido desenvolvida pelo filósofo italiano Antônio Gramsci após a percepção do próprio Marx de que a luta de classes do proletariado teria fracassado como estratégia de luta para implantação do comunismo (Ricardo, 2015).

A estratégia do "marxismo cultural" consistiria em atacar os três pilares da civilização ocidental, a saber: a filosofia grega, o direito romano e a religião judaicocristã e teria sido posteriormente aprimorada pelas feministas dos anos 1960 que vislumbravam, segundo o mesmo Ricardo (2015), o patriarcalismo e a ética sexual burguesa como os inimigos intermediários na destruição da civilização ocidental, pressuposto para a implantação do comunismo.

Tais críticos do "marxismo cultural" identificam que este exerce atualmente domínio hegemônico, conforme se pode inferir desta passagem de Coutinho (2009, p. 43) escrita anos antes do embate parlamentar aqui analisado: 
Para jornalistas como Olavo de Carvalho e Reinaldo Azevedo, que escrevem para grandes jornais da mídia brasileira, Gramsci - e não Lênin - é o verdadeiro inimigo: a teoria gramsciana da hegemonia tem sido apresentada como uma forma sutil de "lavagem cerebral", voltada para destruir o senso comum e preparar para o triunfo do comunismo. Carvalho não hesita em dizer que Gramsci e os gramscianos já venceram no Brasil, pois controlam não só o governo e a burocracia estatal, mas também os meios de comunicação e todo o sistema educacional. De acordo com este jornalista (que gosta de se apresentar como "filósofo"), no Brasil somente as forças armadas resistem, ainda, ao "gramscismo", evidenciando claramente o apelo a uma intervenção militar [...].

Num requerimento direcionado ao MEC, o deputado federal Izalci Lucas (2014) afirma que a estratégia de Marx e Engels de destruir a família já se fazia presente em 1845 no livro A Ideologia Alemã. Numa longa citação, que não cabe aqui reproduzir, apresenta-se como passagem da obra um conjunto de fragmentos retirados de diferentes partes da obra, de modo a inverter a tese marxista, segundo a qual a família patriarcal teria sido determinada pelo aparecimento das primeiras formas de propriedade privada. A inversão consiste em dizer que Marx e Engels sustentavam que a família (genérica e não adjetivada) é que determina a existência da propriedade, e que justamente por isso os marxistas contemporâneos querem destruir a família. No entanto, "o requerimento atribuiu à Marx e Engels um raciocínio que não era deles, mas que seria conveniente que fosse porque assim ficaria mais fácil combater o marxismo" (DERISSO, 2016, p. 6).

Após os embates parlamentares em nível nacional a questão é levada para assembleias legislativas estaduais e câmaras municipais que, em grande maioria, vetaram o debate escolar acerca de questões relacionadas à diversidade, em especial à sexualidade, o que revela o autoritarismo e conservadorismo aplicados à educação escolar por meio do cerceamento e da censura à atividade docente.

A não compreensão do objeto de trabalho docente leva a sociedade à completa confusão acerca daquilo que se pretende ensinar, ocasionando uma falsa divisão entre os valores que os pais sustentam e aqueles que os professores estariam supostamente incutindo em seus filhos.

Na medida que não haja compreensão daquilo que a escola deveria ensinar, a racionalidade dá lugar à mediocridade e ao embate político-ideológico mal fundamentado. 


\section{Projeto Escola Sem Partido e Reforma do Ensino Médio}

Juntamente com os embates acerca da diversidade e questões de gênero, a ideia de que a partir da educação pública ocorre uma doutrinação ideológica ressuscitou o discurso em torno de uma eventual ameaça comunista, cujos principais argumentos foram expostos acima.

Com a queda do Muro de Berlim e fim do chamado "socialismo real" na antiga União Soviética e na Europa do Leste, o movimento socialista sofre um grande golpe no plano internacional. Complementando este quadro, o desmonte do estado de bem-estar na Europa Ocidental produz um do movimento sindical e da força eleitoral dos partidos vinculados aos trabalhadores.

Entretanto, grupos políticos conservadores - principalmente com filiações religiosas que em certo nível expressam um fundamentalismo cristão - acusam os socialistas, marxistas, comunistas etc. de utilizarem-se do sistema educacional para incutirem nas futuras gerações seus ideais revolucionários.

Partindo de tal pressuposto, em 2015, o deputado Izalci Lucas propôs à mesa diretora da Câmara de deputados o projeto "Escola sem partido". Segundo o deputado, o mesmo visa impedir doutrinação ideológica marxista respeitando a plena liberdade de pensamento. O projeto de lei estabelece que:

1 - O professor não se aproveitará da audiência cativa dos alunos para promover os seus próprios interesses, opiniões, concepções ou preferências ideológicas, religiosas, morais, políticas e partidárias.

2 - O professor não favorecerá nem prejudicará ou constrangerá os alunos em razão de suas convicções políticas, ideológicas, morais ou religiosas, ou da falta delas.

3 - O professor não fará propaganda político-partidária em sala de aula nem incitará seus alunos a participar de manifestações, atos públicos e passeatas.

4 - Ao tratar de questões políticas, socioculturais e econômicas, o professor apresentará aos alunos, de forma justa - isto é, com a mesma profundidade e seriedade -, as principais versões, teorias, opiniões e perspectivas concorrentes a respeito da matéria.

5 - O professor respeitará o direito dos pais dos alunos a que seus filhos recebam a educação religiosa e moral que esteja de acordo com suas próprias conviç̧ões.

6 - O professor não permitirá que os direitos assegurados nos itens anteriores sejam violados pela ação de estudantes ou terceiros, dentro da sala de aula. (LUCAS, 2015). 
Os defensores do projeto afirmam combater o abuso da liberdade de ensinar e o fim daquilo que se convencionou chamar de doutrinação marxista. Acerca dos defensores de tal proposição, Araújo, Morais e Souza (2016) entendem que

São do tipo que concebem subjetivamente o texto da Constituição e das Leis como mero ato de sua vontade, pura criação das suas mentes privilegiadas, ou seja, o texto normativo sendo apenas aquilo que eles dizem que é, absolutamente desligado do seu conteúdo; é certo que a interpretação válida da realidade deve partir dessa substância e dos seus acidentes, não de oráculos luminosos, ainda que pretensamente laicos. Isso vale também para o tema em discussão.

Ora, é uma obviedade estabelecer que a liberdade e o pluralismo de ideias dentro da escola não podem se confundir com a partidarização da instituição escolar, o que não se aplica à política em sentido amplo, pois no interior das instituições educacionais manifesta-se o antagonismo entre as classes sociais, que ao invés de ser ignorado pelo bem de uma suposta neutralidade, deve ser debatido, porque a omissão constitui em si um posicionamento, porque cercear a reflexão e o debate no interior da escola sobre as manifestações da diversidade em seus vários aspectos é tornar o trabalho docente estéril e meramente reprodutor do senso comum e de uma visão oficial de mundo que se expressa no âmbito do Estado pela força política que o domina.

Mészaros (2005) afirma que o capital é irreformável e que a educação desde sua base possui interesses antagônicos. Nesse sentido, é fundamental estabelecer a urgência de um debate político plural e diverso que contemple as necessidades políticas da classe a quem se destina a educação.

Preocupante constatar que aquilo que é criminalizado pelo projeto são justamente as pautas de direitos humanos que, erroneamente, passaram a ser tomadas pela maioria dos seus críticos como exclusividade da esquerda. Neste sentido temos a determinação do Tribunal Regional Federal da 1a região de 2017 impondo que o Exame Nacional do Ensino Médio (ENEM) deixe de atribuir nota zero, como vinha procedendo nos últimos anos, para redações que desrespeitassem direitos humanos. Ou seja, aceitase, em nome de uma visão deturpada do que venha a ser liberdade de expressão, que um candidato que defenda ideias de ódio de qualquer natureza (racial, gênero, religião etc.) ingresse numa universidade a partir de critérios puramente técnicos de redação, desprezando aspectos éticos tais como o respeito, a tolerância, a convivência, entre outros. 
Sobre a questão do desrespeito aos direitos humanos, Aragão afirma que:

A laicidade da escola pública, bem como o pluralismo e a democracia, são tarefas fundamentais da escola contemporânea. Debater temas como a emancipação feminina, o racismo e a homofobia não pode ser considerado crime, muito menos abordar a história recente do país, na qual estão presentes movimentos de trabalhadores sem-terra e sem teto, parada gay, manifestações de rua contra a corrupção e até mesmo grupos minoritários que pregam a volta da ditadura militar ou uma escola na qual professores e alunos não podem expressar opiniões. (ARAGÃO, 2016, p. 6)

Num cenário em que as conquistas políticas e sociais, assim como as instituições democráticas, são via de regra questionadas, o crescimento do autoritarismo, o desrespeito ao estado de direito, assim como o ataque generalizado aos direitos trabalhistas (salariais e previdenciários) é potencializado. A educação, no cerne de todos os direitos sociais elementares, sofre com as guinadas políticas e com as ideias deturpadas de direito a um "ensino neutro".

A também recente Reforma do Ensino Médio, implementada nos primeiros dias de um governo duvidoso e travestida de demagogia e marketing positivo, por meio da Medida Provisória (MP) n 746 de 2016, opera mudanças significativas na política educacional no tocante aos objetos de ensino ao suprimir em algumas circunstâncias quatro disciplinas - Sociologia, Filosofia, Artes e Educação Física -, além de abrir a possibilidade para que pessoas com "notório saber" em alguma especialidade da área técnico-profissional possam exercer a atividade docente sem diploma de licenciatura.

Para Ferreti e Silva (2017) a exposição midiática da MP colocou, por um lado, mais ênfase nesses dois aspectos, mas

Escondeu outros de igual ou maior relevância: a pretensão de alterar toda a estrutura curricular e de permitir o financiamento de instituições privadas, com recursos públicos, para ofertar parte da formação.

Outro aspecto que pode ser levantado acerca da Reforma do Ensino Médio, segundo Duarte e Derisso (2017, p. 132), é que a mesma "guarda proximidade com a teoria do capital humano da década de 1960" na medida em "que se orienta para a formação de dois tipos de escola pública, uma orientada para o acesso ao ensino superior e outra para uma educação dita de formação profissional”. Descaracterizando assim, a própria natureza da escola que se associa ao esforço de disseminar os conhecimentos humanos elaborados, os saberes superiores 


\section{Considerações finais}

Os ataques à laicidade das instituições públicas demonstram o relativismo que se impõe quando se trata do cumprimento de legislações que atendam interesses populares. As contradições presentes no texto constitucional levam à dubiedade na interpretação das leis, como é o caso da oferta obrigatória do Ensino Religioso, que apesar de não possuir matrícula obrigatória é tida como parte integrante da formação humana, conforme a LDB. Tal dubiedade leva à descaracterização dos currículos, com apelos muitas vezes ao proselitismo que desrespeita o caráter laico da instituição escolar, o que é sentido, por exemplo, na censura ao trabalho sobre questões de gênero e sexualidade, censura esta que se justifica por ferir determinadas concepções religiosas.

O projeto "Escola sem Partido" é um exemplo de iniciativa alicerçada em pautas religiosas e conservadoras - em alguns aspectos autoritárias -, uma vez que trata de temas relativos aos direitos humanos (LGBTfobia, aborto, legalização de drogas, etc) de maneira enviesada, aplicando discursos ideológicos e partidaristas às bandeiras de importância social, deixando explícita a censura autoritária e reacionária. De modo conclusivo, os autores do tal projeto criticam intensamente o suposto vínculo dos professores, dos livros didáticos e dos próprios programas de ensino - principalmente aqueles relacionados às ciências humanas - com a teoria marxista, e assim procedendo, ainda segundo os autores do Projeto, manipulam ideologicamente o ensino de modo a favorecer a crítica ao sistema capitalista.

Acerca do Projeto Escola sem Partido convém notar que seus proponentes não indicam qualquer constrangimento com a presença de abordagens religiosas - como o próprio Ensino Religioso - ou de caráter liberal - como a educação empreendedora ou empreendedorismo - nas escolas públicas, certamente por não identificarem em tais práticas riscos para o sistema econômico e a ordem social vigentes. Diferente do que ocorre com o marxismo e outras orientações pedagógicas contra hegemônicas.

A Reforma do Ensino Médio indica o grau de autoritarismo de um governo que apresenta os menores índices de apoio e os maiores de rejeição mensurados ao longo da história brasileira. Tal reforma estabelece o caráter de descompromisso com o conhecimento científico historicamente acumulado, uma vez que o desvaloriza em prol de uma suposta educação voltada para a formação profissional, a título de beneficiar uma suposta preferência individual do aluno, que via de regra faz a escolha premido pelas contingências e não por uma opção verdadeira. Nesse sentido direciona-se os 
objetos de ensino de acordo com cada área, relativiza-se a importância dos saberes científicos, filosóficos e artísticos, resultando assim num rebaixamento dos conteúdos curriculares para todos os alunos, uma vez que a fragmentação em áreas permite ao estudante acesso limitado a apenas determinados aspectos do saber humano sistematizado, que poderia ser disponibilizado a todos se a escola se organizasse para tanto.

Enfim, os projetos e medidas apontadas no artigo demonstram a existência de um processo de descaracterização da instituição escolar, mais particularmente o ensino público que passa a ser descolado da realidade social, num sentido amplo para comprometê-la com uma educação pragmática de atendimento das demandas do mercado de trabalho e ideologicamente ancorada numa perspectiva extremada do neoliberalismo.

Na medida em que se impõe no âmbito legal medidas autoritárias que cerceiam a liberdade de reflexão crítica, tais como as preconizadas pelo "Escola sem Partido", ou que se impõem orientações pedagógicas oficiais de caráter neoliberal que visam estritamente a adaptação dos indivíduos aos limites impostos à realidade da sociedade capitalista. Tal cenário possibilita a existência das chamadas teorias ingênuas da educação - definidas por Saviani como teorias não críticas que acreditam ser a escola determinante no processo de transformação social, quando na realidade é em grande medida determinada pela organização social -, ao mesmo tempo em que condena, e até criminaliza as concepções pedagógicas contra hegemônicas, tais como a Pedagogia Histórico-Crítica de Dermeval Saviani, a Pedagogia Libertadora de Paulo Freire e a Pedagogia Libertária dos anarquistas que defendem, cada uma a seu modo, a perspectiva da formação humana integral e a superação da sociedade capitalista.

\section{REFERÊNCIAS}

ARAÚJO, Douglas Santos.; MORAIS, Clarisier Azevedo Cavalcante de.; SOUZA, Ailton Benedito de. Escola sem partido: em defesa da liberdade. Brasília, 2016. Disponível em: <https://jus.com.br/artigos/51017/escola-sem-partido-em-defesa-daliberdade>. Acesso em: 24 abr. 2018.

AZZI, Riolando. A Cristandade Colonial: um projeto autoritário. São Paulo: Paulinas, 1987. 
BARBOSA, Rui. Discurso no Colégio Anchieta. Palavras da juventude. In: Obras completas de Rui Barbosa. Vol. 30. Rio de Janeiro: Fundação Casa de Rui Barbosa, 1903.

BARROS, Roque Spencer Maciel de. Vida Religiosa. In: HOLANDA, Sergio Buarque de. História Geral da Civilização Brasileira. Rio de Janeiro: Bertrand Brasil, tomo II, vol.4, livro 4, capítulo 1, 1997a, p. 329.

BEAVOUIR, Simone. O Segundo Sexo: A experiência vivida. Vol II. São Paulo: Difusão europeia do livro, 1967.

BENTO XVI, Papa. Discurso do Papa Bento XVI à Cúria Romana por ocasião dos votos de Feliz Natal em 22 de dezembro de 2008. Disponível em:

<https://w2.vatican.va/content/benedictxvi/pt/speeches/2008/december/documents/hf_b en-xvi_spe_20081222_curia-romana.html>. Acesso em: 24 abr. 2018.

BIBLIA. Português. A Bíblia Sagrada: Antigo e Novo Testamento. Traduzida em português por João Ferreira de Almeida. Ed. rev. e atual, no Brasil. Brasília/DF: Sociedade Bíblica do Brasil, 1969.

BRASIL. Conselho Federal de Educação do. Parecer 94/71 de 04 de fevereiro de 1971.

BRASIL. Constituição (1824). Constituição do Império do Brasil. Rio de Janeiro, RJ: Paço imperial, 1824.

BRASIL. Constituição (1988). Constituição da República Federativa do Brasil. Brasília, DF: Senado Federal, 1988.

BRASIL. Lei $\mathbf{n}^{\mathbf{0}}$ 9394/96. Lei de diretrizes e bases da educação nacional de 20 de dezembro de 1996.

BRASIL. Lei $\mathbf{n}^{\mathbf{0}}$ 9475/97, de 22 de julho de 1997: dá nova redação ao art. 33 da Lei n 9.394, de 20 de dezembro de 1996, que estabelece as diretrizes e bases da educação nacional. Disponível em: <http://www2.camara.leg.br/legin/fed/lei/1997/lei-9475-22julho-1997-365391-publicacaooriginal-1-pl.html>. Acesso em: 22 abr. 2018.

BRASIL. Plano Nacional de Educação. Câmara de deputados. 2 ed. Brasília, DF, 2015.

BUTLER, Judith. Problemas do gênero: Feminismo e subversão da identidade. Civilização Brasileira: Rio de Janeiro, 2003, p. 24.

COUTINHO, Carlos Nelson. A Presença de Gramsci no Brasil. Revista em Pauta, $\mathrm{n}^{\mathbf{o}}$ 22, Rio de Janeiro: UERJ/Faculdade de Serviço Social, 2009, p. 37-44.

DERISSO, José Luis. Marxismo e História da Família: resposta aos opositores da chamada "ideologia de gênero" na educação. In: Anais do X Seminário Nacional do HITEDBR. Campinas/SP: UniCamp, 2016, p. 1-16. Disponível em: 
<https://www.fe.unicamp.br/eventos/histedbr2016/anais/pdf/1029-2729-1-pb.pdf>. Acesso em: 24 abr. 2018.

DERISSO, José Luis. O ensino religioso na escola pública e a epistemologia dos materiais implementados nas escolas oficiais do estado de São Paulo após a lei $\mathbf{n}^{\circ}$ 9475/97. Dissertação (Mestrado em educação). Universidade Federal de São Carlos, SP. 2006.

DERISSO, Jose Luis.; DUARTE, Rita de Cássia. A reforma neoliberal do Ensino Médio e a gradual descaracterização da escola. Germinal: Marxismo em Educação, v. 9, n. 2, 2017.

DERISSO, José Luis.; SOUZA, Aline Christina de. O pensamento católico no contexto dos embates políticos da década de 1930 no Brasil. RPGE - Revista on line de Política e Gestão Educacional, v. 21, n. 3, p. 1550-1564, set./dez., 2017.

DIETER, Cristina Ternes. As raízes históricas da homossexualidade, os avanços no campo jurídico e o prisma constitucional. Rio de Janeiro, 2011. Disponível em: <http://www.ibdfam.org.br/_img/artigos/As\%20ra\%C3\%ADzes\%20Jhist\%C3\%B3ricas \%2012_04_2012.pdf>. Acesso em: 22 abr. 2018.

ENGELS, Friedrich. A origem da família, da propriedade privada e do estado. Tradução Leandro Konder. 8 ed. Rio de Janeiro: Civilização Brasileira, 1982.

FERRETI, Celso João.; SILVA, Monica Ribeiro da. Reforma Do Ensino Médio no Contexto da Medida Provisória No 746/2016: Estado, Currículo e Disputas por Hegemonia. Educação \& Sociedade, v. 38, n. 139, Campinas, 2017.

IZALCI, Deputado et. al. Requerimento de Informação n. 565/2015 ao MEC, Brasília, 2015. Disponível em: <http://www.camara.gov.br/proposicoesWeb/fichadetramitacao?idProposicao=1279906 >. Acesso em: 05 jun. 2018.

LEITE, Fábio Carvalho. O laicismo e outros exageros sobre a primeira república no Brasil. Religião \& Sociedade, v. 31, n. 1, Rio de Janeiro, p. 32-60, jun., 2011.

MÉSZÁROS, István. A educação para além do capital. 1 ed. São Paulo: Boitempo, 2005.

MOURA, Sérgio Lobo; ALMEIDA, José Maria Gouvêa. A Igreja na Primeira República. In: FAUSTO, Boris. História Geral da Civilização Brasileira. Rio de Janeiro: Bertrand Brasil, tomo III, v. 2, livro 9, 1997.

PINHEIRO, Joely Aparecida Ungaretti. Conflitos entre jesuítas e colonos na América portuguesa: 1640-1700. Tese de doutorado. Universidade Estadual de Campinas, SP, 2007.

RIBEIRO, Vera Masagão. Apresentação. In: FRIGOTTO, G. (ORG). A ideologia do movimento escola sem partido. Frigotto, G. 1 ed, São Paulo: Ação Educativa, 2016. 
RICARDO, Padre. O que você precisa saber para não ser um idiota. Disponível em: $<$ https://padrepauloricardo.org/episodios/o-minimo-que-voce-precisa-saber-para-naoser-um-idiota>. Acesso em: 05 maio 2018.

\section{Como referenciar este artigo}

PACHECO, A. L.; DERISSO, J. L. Negação da laicidade, pensamento autoritário e descaracterização da escola pública no brasil. Revista on line de Política e Gestão Educacional, Araraquara, v. 22, n. 2, p. 646-667, maio/ago., 2018. E-ISSN:1519-9029. DOI: $10.22633 /$ rpge.v22.n2.maio/ago.2018.11667

Submetido em: 02/03/2018

Revisões requeridas: 06/04/2018

Aprovado em: 01/05/2018 